\title{
Use of Electricity in Agriculture
}

\begin{abstract}
CONEERENCES on the immediate problems of 1 crop production are held periodically at the Rothamsted Experimental Station. The twenty-first report* is on the use of electricity in agriculture. The completion of the Grid system and its subsidiary lines in Great Britain is bringing many rural areas within reach of a supply of electricity. While generally admitting its convenience, farmers require more information about costs as compared with internal combustion engines.
\end{abstract}

There is also some confusion in the minds of consumers as to the reasons which lead the companies to ask for guarantees, minimum charges, two part tariffs, etc. Mr. M. M. Harvey, in a paper on the best way to use electric power, gives explanations which appeal to the agriculturist. Discussing the extra cost of rural distribution over town distribution, he explains that if a farmer retails a 100 gallons of milk daily from vans in a few streets, two or three vans can deal with this retailing, and the delivery costs per gallon are low. It is obvious that if he has to retail to the same number of consumers the same number of gallons over the whole of his county, the distribution costs per gallon would be many times his town delivery costs, and he would have to obtain a higher price per gallon to cover this. Similarly, farmers ask why they are having to pay at a higher rate for having a large transformer than for having a small one; apparently they are being penalised for occasionally making a larger demand on the supply system. The explanation given is that if a purchaser take 50 gallons of milk daily as a maximum, then they could budget for sufficient cows to give

* Rothamsted Conferences, 21 : The Use of Electricity in Agriculture: being a Report of a Conference held at Rothamsted on January 29th, 1936, under the Chairmanship of Sir Bernard E. Greenwell Contributions by Sir E. J. Russell, M. M. Harvey, B. A. Keen and G. H. Cashen, F. E. Rowland. C. A. Cameron Brown and others Pp. 77. (Harpenden: Rothamsted Experimental Station, 1936.) 28. this supply. But supposing the purchaser said he required 200 gallons on one day of the year, then the farmer would have to keep a larger herd simply to supply this one day's demand. He would therefore be justified in charging extra for the availability of a larger supply of milk occasionally.

Everyone admits the great convenience of electricity for light and power. It saves a great deal of labour when a piece of work can be started and finished simply by pressing a button. Modern electric motors are so good, and their moving parts so well enclosed, that a breakdown is a very rare occurrence. The supply companies are willing to test them periodically. A farmer who contemplates installing electricity will find in Mr. Harvey's paper data about farms of all kinds, some of which will doubtless be like his own.

In a foreword by Sir John Russell, it is pointed out that the experiments made at Rothamsted show that for the same grinding rate and fineness of grinding, $4 \cdot 6$ units of electricity per hour were equivalent to $2 \cdot 3$ pints of Diesel oil per hour. At the price paid $(1 \cdot 42 d$. per unit), electric power came out a little more expensive than paraffin, when overhead costs were neglected. When such costs were taken into account, however, electric power was cheaper than paraffin, although a little more expensive than Diesel oil. Electric power in its ease of application and cleanliness possesses many advantages. No attempt to estimate the value of these advantages has been made.

In the present report nothing is said about electrical ploughing or electrical discharges over crops. The latter is now believed to have little, if any, value. The Conference discussed only the practical applications of electricity. In future conferences, horticultural possibilities such as obtaining early crops by heating the soil will doubtless be discussed.

\section{Organisation of Plant Cytoplasm}

\begin{abstract}
A VERY valuable summary of modern views on this difficult subject will be found in two little monegraphs* by Prof. A. Guilliermond of the Sorbonne, dealing respectively with the 'chondriome' and 'vacuome'. These two names are given by the author to two distinct types of morphological unit which can be found in varying form in the eytoplasm throughout the life of the cell. The cytoplasm itself is regarded as an optically empty colloidal solution of long colloidal thread molecules (proteins, etc.), which have imbibed so much water that their refractive index approximates to their aqueous medium.

*Exposés de biologie (embryologie et histogenèse). Par Prof. A. Guilliermond. 2: Les constituants morphologiques du cytoplasme le chondriome. Pp. 128. 20 francs. 3: Les constituants morphologiques du cytoplasme ; le système vacuolaire ou vacuome. Pp. 108. 18 francs. (Actualités scientiflques et industrielles, 170, 171.) (Paris : Hermann et Cie, 1934.)
\end{abstract}

They thus give the properties of a viscous sol to the cytoplasm, but the thread molecules link up at any surface to form an elastic solid plasma membrane.

The vacuome and chondriome systems can be distinguished by their behaviour to vital stains. The vacuome system stains heavily when the living cell is in dilute solutions of neutral red. In the meristem cell the vacuome system thus revealed is a concentrated colloidal solution dispersed in small drops or threads amongst the cytoplasm, but cell expansion is largely determined by the entry of water into this system, which then coalesces in stages into the wellknown 'vacuole', in which the colloidal substances are dispersed in dilute solution and precipitate as red-staining granules in the presence of neutral red.

The chondriome system does not stain in vitam, but subvitally will take up Janus green; thus 
simultaneous demonstrations of the two systems is temporarily possible with neutral red and Janus green.

The lipin nature of the chondriome makes it disappear in acetic acid or alcohol fixatives unless unsaturated fatty acids are first oxidised to hydroxy acids, less soluble in alcohol and xylol, as by treatment with chromic acid or osmic acid, etc. The vexed questions of the relation of the chondriome system to the plastids; of the methods of multiplication in embryonic cells of both vacuome and chondriome, and of the relation of the vacuome system to the Golgi network or the Holmgren canals are discussed very concisely and with a full citation of the work upon animal cytology which will be very valuable to the botanist.

\section{Zooplankton of the Great Barrier Reef*}

$\mathrm{F}^{\mathrm{o}}$ OLLOWING the general report on the zooplankton of the Great Barrier Reef (noticed in NATURE of August 3, 1935) more detailed work on the different groups is now in progress. The pelagic animals belonging to the Tunicata, Mollusca and Siphonophora are here discussed. Comparison with other expeditions is emphasised, particularly the Siboga Expedition, but in this year's work on the Barrier Reef a continuous series of samples is available, giving valuable information as to seasonal distribution and life-histories which has never before been obtained to such an extent. Identification of species has already been made by Miss A. B. Hastings (Tunicata), Mr. A. K. Totton (Siphonophora) and Miss Anne L. Massy (Pteropoda), whilst Prof. Paul Pelseneer has looked through the larval gastropods. Identification was not possible in the last group and in the larval lamellibranchs, but reports on the Tunicata and Siphonophora have already been published (in Vol. 4 of these reports).

The larger tunicates were abundant in the stramin net, but among the great numbers of small animals retained by the silk net they were less important. On the average, the tunicates formed one half of the total number of animals caught in the stramin net, while in the coarse and fine nets, oblique hauls, these proportions were only $5 \cdot 7$ per cent and $2 \cdot 7$ per cent respectively. The total collections comprised three species of Doliolids, six species of Salps and eight species of Appendicularians; but the only species which played an important part in the composition of the plankton at the weekly stations were Salpa democratica, Oikopleura rufescens and O. longicauda. On the average for the year, the Thaliacea far out. numbered the Appendicularians in the stramin catches; but there were violent fluctuations in the composition of the Tunicata due to swarming of certain species, especially Salpa democratica and Megalocercus huxleyi. In the coarse silk net small appendicularians preponderated, except in months when swarms of salps were met with. In both nets the Doliolids were on the whole of small significance.

Easily the most abundant salp was Salpa democratica, with two maxima-September-January, and April-May; during the remaining months it was almost completely absent. On only a few days really large catches were made when the salps were often to be seen in the sea in enormous numbers. The spring increases occurred at full moon, the later increases at or after new moon. The authors are of opinion, however, that the salp increases do not really indicate a lunar periodicity in breeding, but that they indicate successive outbursts of reproduction in the waters round Low Island, the sudden peaks being due to swarms drifting up the Barrier Reef Lagoon. The chief increases occur when the temperature is between $24^{\circ}$ and $28^{\circ} \mathrm{C}$. It is probable that salinity has no effect on their presence, whilst temperature is important. The comparatively few salps in the collection may indicate that those caught are the better able to live in shallow coastal water, and the same may hold good for appendicularians, or it may be that in some years other species will be found which, owing to sparse distribution, were not brought near the coast in this one year.

Of the Appendicularians treated as a whole, Oikopleura rufescens and $O$. longicauda are the most abundant, the maximum occurring in January and February, coinciding with the highest temperature and decreasing salinity. The Barrier Reef collections are so far the only records giving a full picture of a year's course in a region in the Pacific where warm tropical water conditions exist throughout the year. The absence of Oikopleura dioica is striking. Of the Mollusca, the pteropods are much the most important, although there were numbers of larval gastropods and lamellibranchs at times. Here again the pteropod records contain the first contribution towards their seasonal study in the tropics. Only three are important in the coastal waters of the Barrier Reef, Creseis acicula, C. virgula and Cavolinia longirostris, agreeing with the results of the Siboga Expedition. The creseids extend normally nearer the coast than the other genera.

Siphonophores were much more abundant than medusæ and only a few coral planulæ were caught. Of the thirty-two species of Siphonophores, twenty from the Barrier Reef Lagoon, two species predominated, Lensia subtiloides and Diphyes chamissonis, and these were responsible for the main fluctuations in abundance during the year. Many species were absent because of low salinity during the heavy rains, but they were probably present outside the reef. That the three species Diphyes chamissonis, Lensia subtiloides and Enneagonum hyalinus were present in the lagoon during the period of low salinity points to the possibility that these species are specially adapted to life in shallow coastal waters. This seems to be the first time that any siphonophores have been definitely recognised as coastal species in a predominantly oceanic group.

* British Museum (Natural History). Great Barrier Reef Expedition, 1928-29. Scientiflc Reports. Vol. 2, No. 7: The Zooplankton. 4: The Occurrence and Seasonal Distribution of the Tunicata, Mollusea and Coelenterata (Siphonophora). By F. S. Russell and J. S. Colman. Pp. 203-276. (London : British Museum (Natural History), 1935.) 58. 